\title{
In vitro assessment of the dual-targeting behavior of a peptide-based magnetic resonance imaging contrast agent
}

\author{
YUPING YANG $^{1,2}$, KAICHAO YU $^{1}$, HAILU ZHANG $^{2}$, JIANWU DAI $^{3,4}$ and ZONGWU DENG ${ }^{2}$ \\ ${ }^{1}$ School of Chemistry and Chemical Engineering, Huazhong University of Science and Technology, Wuhan, \\ Hubei 430007; Divisions of ${ }^{2}$ Nanobionics and ${ }^{3}$ Nanobiomedicine, Suzhou Institute of Nanotech and Nanobionics, \\ Chinese Academy of Sciences, Suzhou, Jiangsu 215123; ${ }^{4}$ State Key Laboratory of Molecular Developmental Biology, \\ Institute of Genetics and Developmental Biology, Chinese Academy of Sciences, Beijing 100190, P.R. China
}

Received August 8, 2013; Accepted October 31, 2013

DOI: 10.3892/ijmm.2013.1551

\begin{abstract}
In this study, a peptide-based dual-targeting magnetic resonance imaging (MRI) contrast agent (S8) was designed and synthesized. Arg-Gly-Asp (RGD) and Asn-Gly-Arg (NGR) were combined in the targeting vector so as to allow binding, on the surface of tumor cells, to integrin $\alpha_{v} \beta_{3}$ and aminopeptidase $\mathrm{N}\left(\mathrm{CD}_{13}\right)$, respectively. The longitudinal relaxivity $\left(\mathrm{r}_{1}\right)$ value of S8 was $8.297 \mathrm{mM}^{-1} \mathrm{sec}^{-1}$ at a magnetic field of $11.7 \mathrm{~T}$, which is approximately double the $r_{1}$ value $\left(4.25 \mathrm{mM}^{-1} \mathrm{sec}^{-1}\right)$ of Magnevist, a commercially available contrast agent. MDA-MB231 human breast cancer cells (which overexpress $\alpha_{v} \beta_{3}$ ) and human prostate cancer cells PC-3 (which overexpress $\mathrm{CD}_{13}$ ) were used to investigate the tumor-targeting behavior of S8. The results from the present study indicate that the designed contrast agent, S8, targets both MDA-MB-231 and PC-3 cells.
\end{abstract}

\section{Introduction}

Targeting technology is used in molecular imaging to improve the efficacy of magnetic resonance imaging (MRI) contrast agents and to increase their concentration in the nidus area so as to enhance image visibility $(1,2)$. Numerous types of targeting technology have been used to achieve these goals, with the peptide-based targeting vector technology becoming increasingly popular for diagnostic and therapeutic applications (3-5). Peptides have very good biocompatibility, limited immunogenicity in the body and non-specific uptake by the liver or the reticuloendothelial system (6). The synthesis of peptides is simple and cost-efficient, the design of the peptide chain is flexible, while ameliorating their structure and improving their efficacy can be easily accomplished by replacing amino acid residues in the peptide chain. Researchers can design and expe-

Correspondence to: Professor Kaichao Yu, School of Chemistry and Chemical Engineering, Huazhong University of Science and Technology, 1037 Luoyu Road, Wuhan, Hubei 430007, P.R. China E-mail: 421780897@qq.com

Key words: Arg-Gly-Asp, Asn-Gly-Arg, dual targeting, magnetic resonance imaging contrast agent diently synthesize the corresponding peptide to meet custom medical purposes. The specific binding of functional peptides to their receptors facilitates the research of targeting contrast agents $(7,8)$.

Integrin $\alpha_{v} \beta_{3}$ and aminopeptidase $\mathrm{N}\left(\mathrm{CD}_{13}\right)$ are expressed in sprouting endothelial cells and in various tumor cells, but show restricted expression in normal cells, which renders them suitable receptors for tumor-targeting agents (9). Since the Arg-Gly-Asp (RGD) peptide is specific to $\alpha_{v} \beta_{3}(10,11)$, numerous applications based on the $\mathrm{RGD} / \alpha_{\mathrm{v}} \beta_{3}$ targeting delivery system have been reported in molecular imaging $(12,13)$. Similarly, the Asn-Gly-Arg (NGR) peptide is a specific recognition sequence of $\mathrm{CD}_{13}$ (14). The $\mathrm{NGR} / \mathrm{CD}_{13}$-based targeting delivery system is frequently reported in drug design for the treatment of cancer $(15,16)$ and as an imaging system $(17,18)$. However, to our knowledge, no study to date has investigated the potential of the combination of RGD with NGR as a targeted delivery system. Promising results from such a study may prove meaningful for the therapy and diagnosis of tumors.

In the present study, we designed a peptide sequence which consists of the two motifs, RGD and NGR. The peptide sequence was then coupled to the complex gadolinium (Gd)-1,4, 7,10-tetraazacyclododecane-1,4,7,10-tetraacetic acid (DOTA) to investigate its efficacy as a tumor-targeting contrast agent. The contrast agent can target $\alpha_{\mathrm{v}} \beta_{3}$ and $\mathrm{CD}_{13}$ as a dual-targeting contrast agent.

$\alpha_{v} \beta_{3}$ and $\mathrm{CD}_{13}$ are tumor biomarkers; however, these proteins are not highly expressed in all tumor types. If each of the RGD and NGR peptides in the dual-targeting contrast agent binds to $\alpha_{\mathrm{v}} \beta_{3}$-overexpressing and $\mathrm{CD}_{13}$-overexpressing tumor cells, respectively, then the contrast agent can detect both types of tumor, and thus the combination of RGD and NGR may improve tumor detection rates. In tumor cells expressing both $\alpha_{\mathrm{v}} \beta_{3}$ and $\mathrm{CD}_{13}$, the two motifs of RGD and NGR can simultaneously bind to the target tissue, which enhances the incorporation of the contrast agent; the higher concentration of the contrast agent in the tumor area will improve imaging visibility. In this study, the targeting behavior of the contrast agent that we designed was examined using MDA-MB-231 human breast cancer cells (which overexpress $\left.\alpha_{v} \beta_{3}\right)(19,20)$ and $\mathrm{PC}-3$ human prostate cancer cells (which overexpress $\mathrm{CD}_{13}$ ) (21). 


\section{Materials and methods}

Synthesis of 4,7,10-tricarboxymethyl-tert-butyl ester 1,4, 7,10-tetraazacyclododecane-1-acetate [DOTA $(t B u)_{3}$ ]. $\operatorname{DOTA}(\mathrm{tBu})_{3}$ was prepared by a multistep synthesis procedure starting from cyclen hydrochloric salt. The synthesis was based on a previous study (22). The procedure is outlined in Fig. 1.

Synthesis of ligand (S7). The peptide was assembled using manual solid phase Fmoc peptide chemistry, as previously described (23) and outlined in Fig. 2. N-Fmoc-Lys (Dde)-OH was selected as an anchoring site to conjugate with $\operatorname{DOTA}(\mathrm{tBu})_{3}$ using its $\omega$-amino acid. The protective group, Dde, of N-Fmoc-Lys (Dde)-OH was removed by incubation with $2 \%$ hydrazine monohydrate in dimethylformamide (DMF, $25 \mathrm{ml} / \mathrm{g}$ ) at room temperature for $3 \mathrm{~min}$. The coupling efficiency (>99\%) in every coupling step was determined by measuring residual free amine with the quantitative ninhydrin assay, as previously described (24).

The intramolecular disulfide bond was formed between the two cysteine (Cys) residues. A $5 \mathrm{M} \mathrm{I}_{2}$ solution in DMF was added to the reaction system with continuous stirring for $3 \mathrm{~h}$, to remove the side-protection group, $\mathrm{Acm}$, from Cys (Acm)- $\mathrm{OH}$ and to simultaneously oxidize the two sulfydryls, so as to form a disulfide bridge. Excessive iodine was removed with sodium thiosulphate $\left(\mathrm{Na}_{2} \mathrm{~S}_{2} \mathrm{O}_{3} \cdot 5 \mathrm{H}_{2} \mathrm{O}\right.$, aq).

The crude product was cleaved from the 4-(2',4'-dimethoxyphenyl-Fmoc-aminomethyl)-phenoxyacetamido-norleucyl (Rink Amide) MBHA resin by treatment with a mixture of $90 \%$ trifluoroacetic acid (TFA), 2\% p-cresol, 5\% thioanisole and $3 \%$ ethanedithiol for $4 \mathrm{~h}$ at $0^{\circ} \mathrm{C}$. Residual protective groups were removed. Subsequently, the free peptide was precipitated in cold $\mathrm{Et}_{2} \mathrm{O}$ and centrifuged. The sediment was collected and dissolved in water. Semi-preparative reversed phase (RP) high-performance liquid chromatography (HPLC) purification and subsequent lyophilization yielded the white powder product, S7 (230.1 mg, yield $21.5 \%$ based on resin loading). Analytical RP HPLC estimated the purity of S7 at $98 \%$, and the product was eluted in a linear gradient of $0-30 \% \mathrm{CH}_{3} \mathrm{CN}-\mathrm{H}_{2} \mathrm{O}$ in $0.1 \%$ TFA for $30 \mathrm{~min}$.

Gd complex S8. The ligand S7 $(20.2 \mathrm{mg}$ from a $10.2 \mu \mathrm{mol}$ comcentration) was dissolved in $10 \mathrm{ml}$ of demineralized water. The $\mathrm{pH}$ of the aqueous solution was adjusted to 6.5-7.0 by the addition of $0.25 \% \mathrm{NH}_{4} \mathrm{OH}(\mathrm{aq})$. Subsequently, a solution of $3.75 \mathrm{mg}$ Gd chloride hexahydrate in $1.0 \mathrm{ml}$ water $(10.0 \mu \mathrm{mol}$, 0.99 equivalents) was added. The mixture was vigorously stirred for $4 \mathrm{~h}$ at room temperature with the $\mathrm{pH}$ maintained at 6.5-7.0 by the addition of $0.25 \% \mathrm{NH}_{4} \mathrm{OH}$. The crude product was purified using a dialysis bag, and was condensed and lyophilized. The resulting Gd complex, S8, was a white hygroscopic powder (20.97 mg, yield 97.2\%).

Cell culture. MDA-MB-231 cells were cultured in Dulbecco's modified Eagle's (DMEM) medium supplemented with $10 \mathrm{U} / \mathrm{ml}$ penicillin, $10 \mu \mathrm{g} / \mathrm{ml}$ streptomycin and $10 \%$ fetal bovine serum (FBS). All media, serum and antibiotics were provided by Invitrogen Life Technologies (Carlsbad, CA, USA). Cells were cultured in a $5 \% \mathrm{CO}_{2}$ atmosphere at $37^{\circ} \mathrm{C}$ under $95 \%$ humidity, within a ThermoFisher Scientific (Rockford, IL, USA) incu-

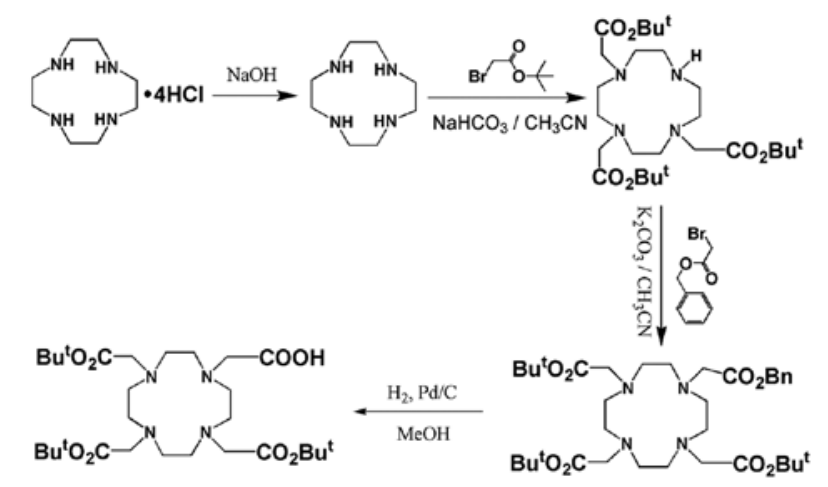

Figure 1. Synthesis of 4,7,10-tricarboxymethyl-tert-butyl ester 1,4,7,10-tetraazacyclododecane-1-acetate $\left[\mathrm{DOTA}(\mathrm{tBu})_{3}\right]$.

bator 3111 . PC-3 cells were cultured as described above, in F12 medium.

Relaxivity measurements. To determine the longitudinal relaxivity $\left(r_{1}\right)$ value, seven different concentrations $(0,0.05,0.1,0.2$, $0.4,0.8$ and $1.6 \mathrm{mM}$ ) of the contrast agents, S8 and Magnevist (serving as the control), were prepared. The relaxation time $\left(T_{1}\right)$ of these solutions was measured on a Bruker AVANCE III 500WB Spectrometer (Bruker NMR, Germany) with an 89-mm vertical-bore magnet of $11.7 \mathrm{~T}$ with the following parameters: $20^{\circ} \mathrm{C}$, Multi-Slice Multi-Echo repeat time (TR), 5,000 msec; echo time (TE), $7.6 \mathrm{msec}$; and average signal, 2. Linear fitting of the reciprocal of the $T_{1}$ relaxation time vs. the Gd concentration $(\mathrm{mM})$ was used to estimate $1 / \mathrm{T}_{1}\left(\mathrm{r}_{1}, \mathrm{mM}^{-1} \mathrm{sec}^{-1}\right)$.

Cellular uptake of contrast agents. MDA-MB-231 or PC-3 cells were seeded in 24 -well culture plates $\left(5 \times 10^{5}\right.$ cells/well) and were cultured overnight to allow the cells to adhere to the plate wall. The cells were then divided into two groups: group 1 was treated in triplicate with eight different concentrations $(0.05-1.2 \mathrm{mM})$ of $\mathrm{S} 8$ for $8 \mathrm{~h}$, and group 2 was treated with Magnevist with the same method. Following incubation, the nutrient solution was discarded and the cells were washed twice with phosphate-buffered saline (PBS) to remove unbound $\mathrm{Gd}$ complexes. The Gd content of the cells was determined by inductively coupled plasma atomic emission spectroscopy (ICPAES) in a PerkinElmer (Waltham, MA, USA) Optima 8000 spectrometer. The results are expressed as the means $\pm \mathrm{SD}$.

Cell imaging. MDA-MB-231 or PC-3 cells were seeded in 24-well culture plates $\left(5 \times 10^{6}\right.$ cells/well). The cells were then grouped and incubated as described above. All samples were fixed in $1 \%$ agarose and visualized using a 11.7 T NMR spectrometer. $\mathrm{T}_{1}$-weighted images were obtained by multi-slice multi-echo imaging, using inversion times 50, 100, 200, 400, $700,1,400,2,000$ and 2,800 msec, a TE of $6 \mathrm{msec}$ and an echo train length of 8 at a TR of $300 \mathrm{msec}$. All images were obtained from a single axial slice of $3 \mathrm{~mm}$ in a $20 \times 15 \mathrm{~cm}^{2}$ field



WST. The WST assay was performed to examine cell proliferation and cytotoxicity. The MDA-MB-231 or PC-3 cells were seeded in quintuplicate in 96 -well plates $\left(1 \times 10^{4}\right.$ cells in $100 \mu 1$ culture medium) and were maintained for $24 \mathrm{~h}$. The cells were 


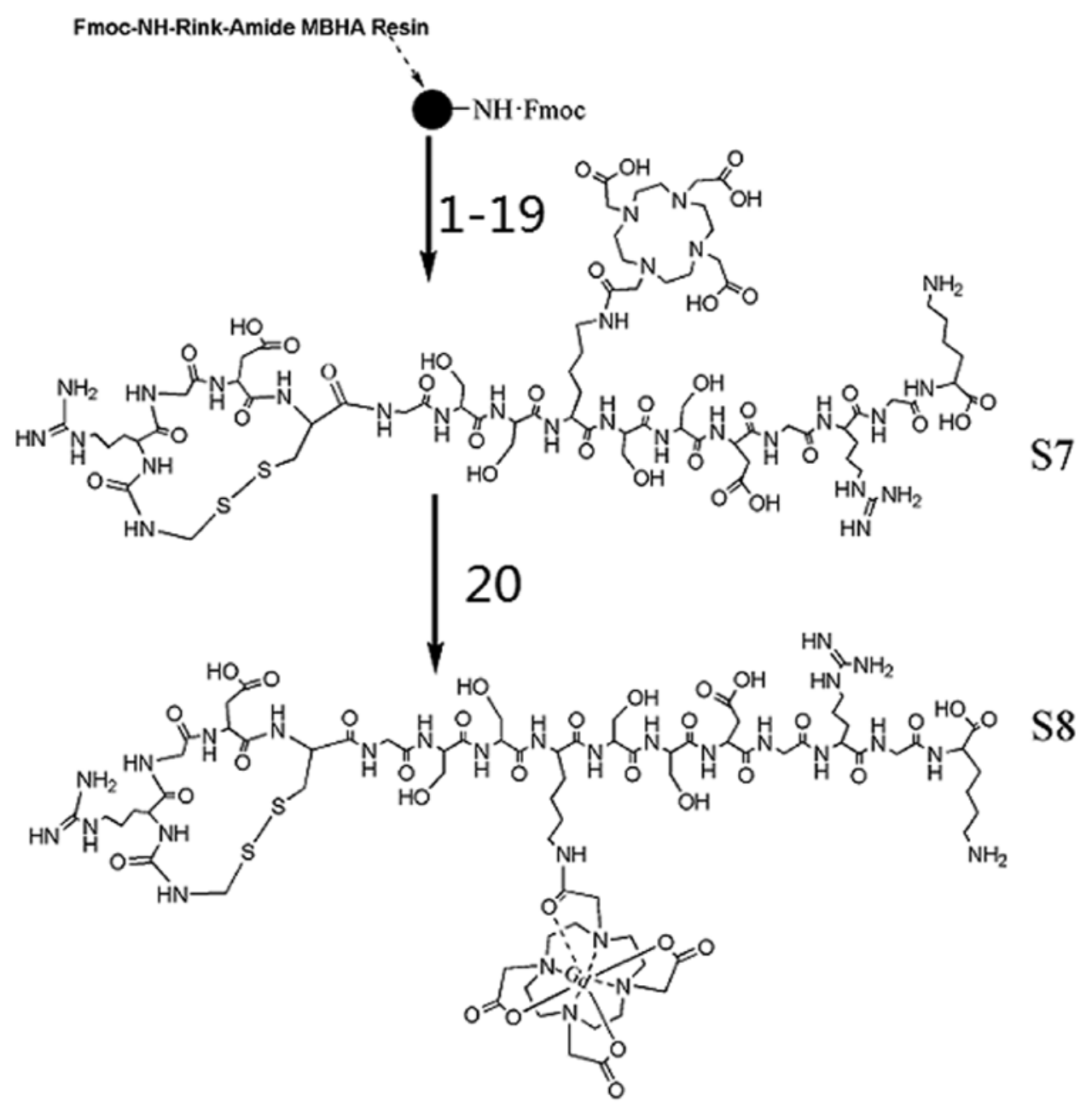

Figure 2. Synthesis of the gadolinium (Gd) complex S8 starting from Rink Amide MBHA resin. All 16 amino acids were coupled using the following steps. First, the $\mathrm{N}_{\alpha-}$ Fmoc protective group was removed by the addition of $20 \%$ piperdine in dimethylformamide (DMF) (two times) for 5 min. After alternate washes with DMF and dichloromethane (DCM), a mixture solution of amino acid (three equivalents), HBTU (three equivalents), HOBt (three equivalents) and DIPEA (six equivalents) in $10 \mathrm{ml}$ DMF was added into the reaction. The reaction was completed by frothing agitation with nitrogen for $2 \mathrm{~h}$ to generate a peptide bond. The $\mathrm{N}_{\omega}$-Dde protective group of middle Lys was removed using a solution of $2 \%$ hydrazine monohydrate in DMF (25 g/ml) at $\mathrm{rt}$ for $3 \mathrm{~min}$ and then the DOTA(tBu$)_{3}$ was coupled with the middle Lys using the same method as described above for the amino acids. Coupling sequences: 1, Fmoc-lys(Boc)-OH; 2, Fmoc-Gly-OH; 3, Fmoc-Arg(Pbf)-OH; 4, Fmoc-Gly-OH; 5, Fmoc-Asp(otBu)-OH; 6, Fmoc-Ser(tBu)-OH; 7, Fmoc-Ser(tBu)-OH; 8, Fmoc-lys(Dde)-OH; 9, DOTA(tBu) $)_{3}$; 10, Fmoc-Ser(tBu)-OH; 11, Fmoc-Ser(tBu))-OH; 12, Fmoc-Gly-OH; 13, Fmoc-Cys(Acm)-OH; 14, Fmoc-Asn(Trt)-OH; 15, Fmoc-Gly-OH; 16, Fmoc-Arg(Pbf)-OH; 17, Fmoc-Cys(Acm)-OH; 18, $5 \mathrm{M} \mathrm{I}_{2}$ in DMF/ $\mathrm{Na}_{2} \mathrm{~S}_{2} \mathrm{O}_{3} \cdot 5 \mathrm{H}_{2} \mathrm{O}$, aq; 19, TFA:p-cresol:thioanisole:ethanedithiol (90:2:5:3); $20, \mathrm{GdCl}_{3} \cdot 6 \mathrm{H}_{2} \mathrm{O} / \mathrm{NH}_{3} \cdot \mathrm{H}_{2} \mathrm{O} \mathrm{pH}$ 6.5-7.0, room temperature, $3 \mathrm{~h}$.

then incubated for $48 \mathrm{~h}$ with $\mathrm{S} 8$ at different Gd concentrations, the nutrient solution was discarded and the cells were washed with PBS buffer three times. Subsequently, fresh culture medium and WST were added. Cell viability was measured following the manufacturer's instructions (Beyotime Institute of Biotechnology (Haimen, China). The data are expressed as the means \pm SD. The same concentration of Magnevist was used in the control experiments.

\section{Results}

Target product. The Gd complex S8 is a white hygroscopic powder. Chemical characterization of S7 and S8 was performed by high resolution electron spray ionization mass spectrometry (HRESIMS) using the 6220 Accurate-Mass TOF LC/MS spectrometer (Agilent Technologies, Santa Clara, CA, USA). HRESIMS revealed that the $\mathrm{S} 7[\mathrm{M}+\mathrm{H}]^{+}$mass was
1983.3092 and the S7 $[\mathrm{M}+2 \mathrm{H}]^{2+}$ mass was 992.1147 (Fig. 3A), in agreement with their theoretical mass values (1983.8530 for $[\mathrm{M}+\mathrm{H}]^{+}$and 992.4265 for $[\mathrm{M}+2 \mathrm{H}]^{2+}$, respectively). The S8 $[\mathrm{M}+2 \mathrm{H}]^{2+}$ mass was similarly shown to be 1069.6948 and the S8 $[\mathrm{M}+3 \mathrm{H}]^{3+}$ mass was 713.3152 (Fig. 3B), in agreement with their theoretical mass values $\left(1069.8770\right.$ for $[\mathrm{M}+2 \mathrm{H}]^{2+}$ and 713.5847 for $[\mathrm{M}+3 \mathrm{H}]^{3+}$, respectively). The $\mathrm{Gd}$ content of S8 was determined by ICP-AES. The observed value of the Gd content was $98.3 \%$ of the theoretical value.

Relaxivity. The $\mathrm{r}_{1}$ value of $\mathrm{S} 8$ was estimated to be $8.297 \mathrm{mM}^{-1} \sec ^{-1}$ (Fig. 4), that is, higher than the $\mathrm{r}_{1}$ value of Magnevist $\left(4.30 \mathrm{mM}^{-1} \mathrm{sec}^{-1}\right)$, which is a ripe contrast agent widely used in clinical applications.

Targeting behavior of $S 8$. We investigated the targeting behavior of S8 in two cell lines (MDA-MB-231 and PC-3). 

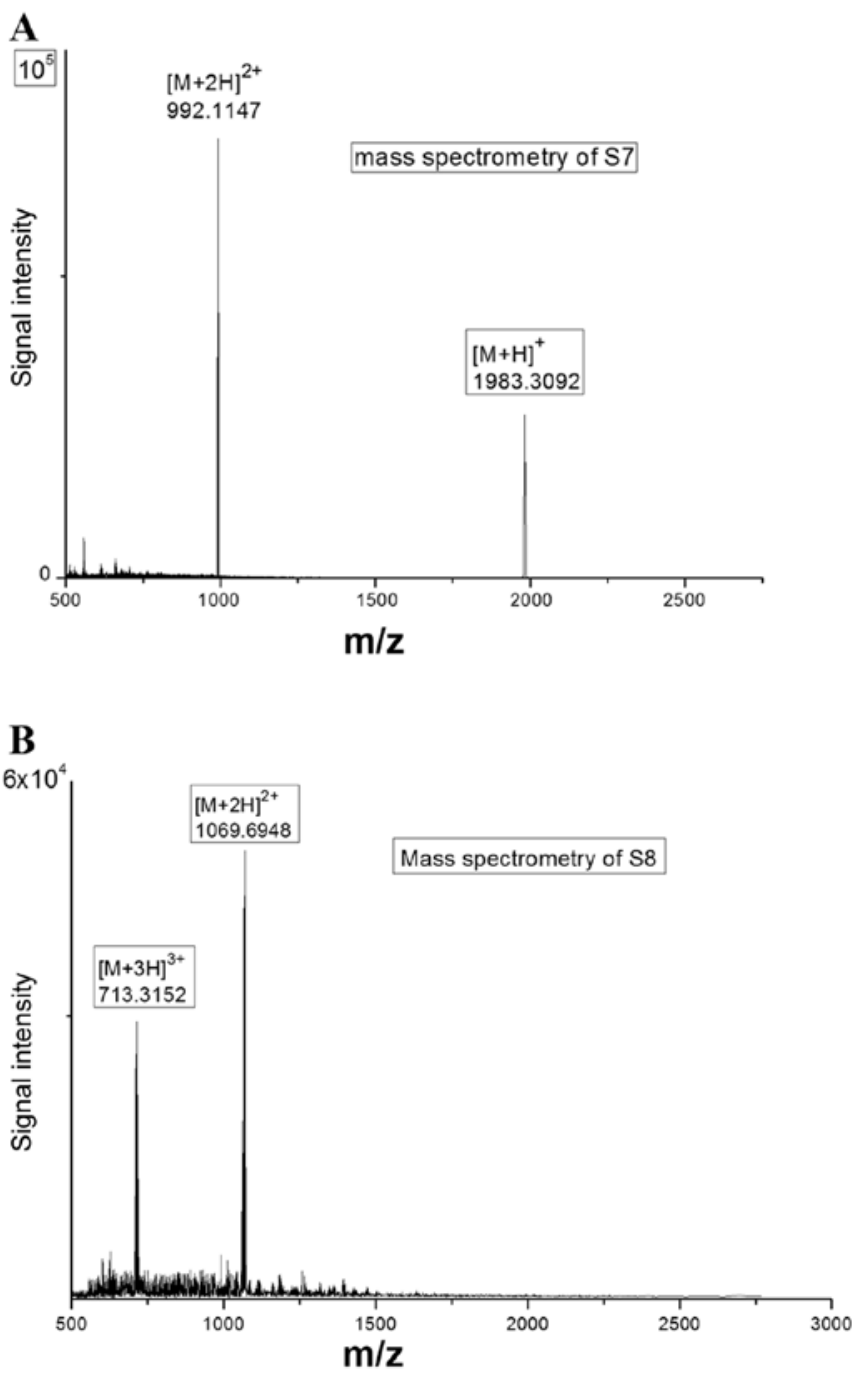

Figure 3. High resolution electron spray ionization mass spectrometry (HRESIMS) spectra of (A) S7 and (B) S8.

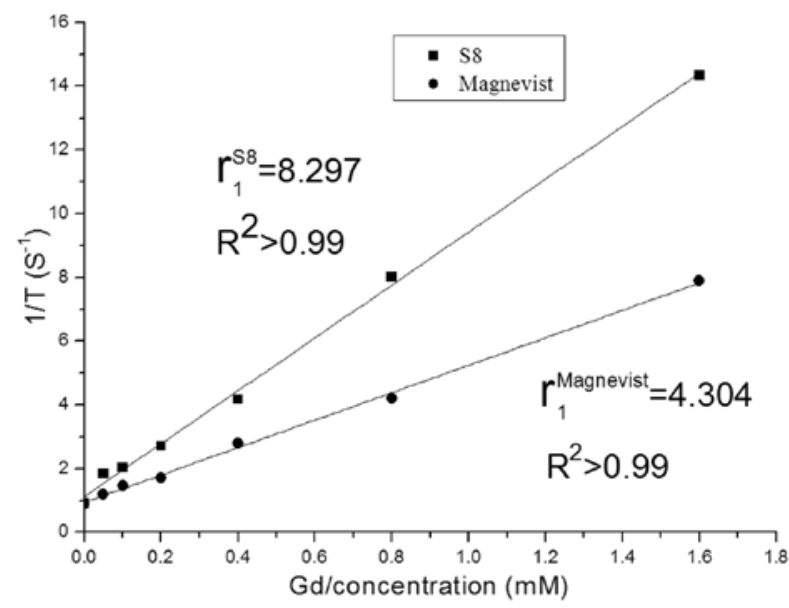

Figure 4. Plot of $1 / \mathrm{T} 1$ vs. the concentration of the contrast agent in aqueous solution measured in a $11.7 \mathrm{~T}$ spectrometer. Longitudinal relaxivity (r1) of S8 and Magnevist is 8.297 and 4.304, respectively.

Fig. 5 shows the contrast agent uptake quantity of MDA-MB231 and PC-3 cells at different concentrations of S8 or Magnevist.
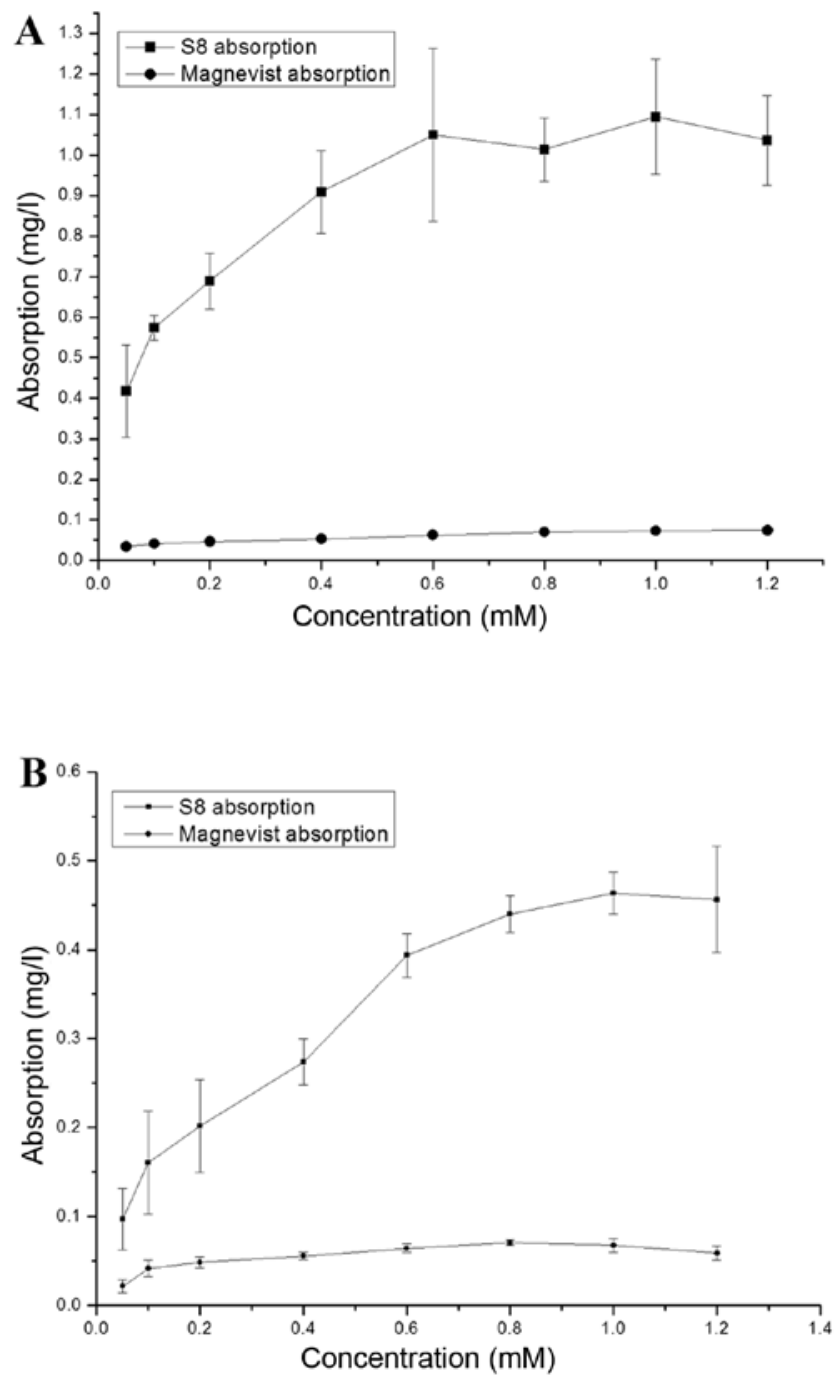

Figure 5. (A) Uptake quantity of S8 and Magnevist in (A) MDA-MB-231 cells and (B) PC-3 cells. The cells $\left(5 \times 10^{5}\right.$ cells/well) were cultured with S8 or Magnevist for $8 \mathrm{~h}$. Values represent the means $\pm \mathrm{SD}$ of three independent experiments.

We found that, within a certain concentration range, the uptake quantity increased linearly with the increase in the concentration of S8 added into the cells. In the MDA-MB-231 cells, the uptake quantity reached saturation at $0.6 \mathrm{mM}$ of added S8, while in the PC-3 cells, saturation was reached at $1.0 \mathrm{mM}$ of S8. At the same concentration of S8, the quantity absorbed by the MDA-MB-231 cells was higher than that absorbed by the PC-3 cells. A possible explanation for this may be that $\alpha_{v} \beta_{3}$ expression in the MDA-MB-231 cells is higher than $\mathrm{CD}_{13}$ expression in the PC-3 cells. The two cell lines displayed comparable uptake quantity for Magnevist. The uptake quantity was in the low range and were altered only slightly in response to changes in the concentrations of S8 added to the cells.

Cell imaging. For both cell lines examined, much clearer and more visible images of cells incubated with S8 (above a certain concentration value) were obtained compared with the cells incubated with Magnevist, (Fig. 6). In the MDA-MB-231 cells, this value was $0.2 \mathrm{mM}$ and in the PC-3 cells, it was $0.6 \mathrm{mM}$. 
A MDA-MB-231

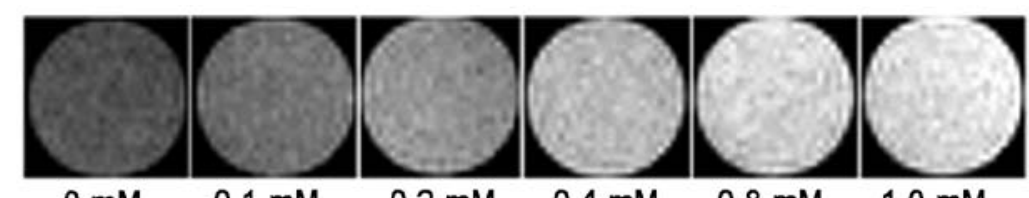

S8 concentration

$0 \mathrm{mM}$

$0.1 \mathrm{mM}$

$0.2 \mathrm{mM} \quad 0.4 \mathrm{mM}$

$0.8 \mathrm{mM}$

$1.0 \mathrm{mM}$



Magnevist concentration

$0 \mathrm{mM}$

$0.1 \mathrm{mM}$

$0.2 \mathrm{mM}$

$0.4 \mathrm{mM}$

$0.8 \mathrm{mM}$

$1.0 \mathrm{mM}$

B PC-3 cell imaging

S8 concentration
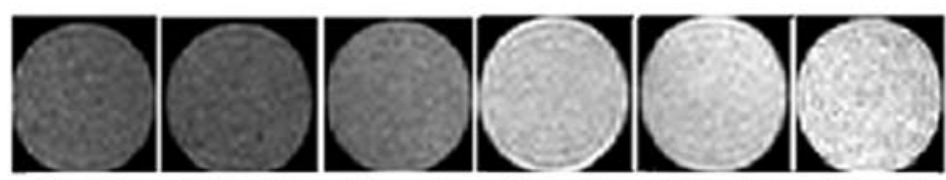

$0 \mathrm{mM}$

$0.2 \mathrm{mM}$

$0.4 \mathrm{mM}$

$0.6 \mathrm{mM}$

$0.8 \mathrm{mM} \quad 1.0 \mathrm{mM}$

Magnevist concentration
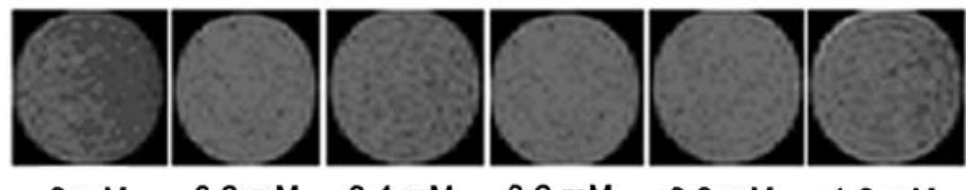

$0 \mathrm{mM}$

$0.2 \mathrm{mM}$

$0.4 \mathrm{mM}$

$0.6 \mathrm{mM}$

$0.8 \mathrm{mM}$

$1.0 \mathrm{mM}$

Figure 6. $\mathrm{T}_{1}$-weight imaging of (A) MDA-MB-231 cells and (B) PC-3 cells in a 11.7-T NMR spectrometer. Cells were fixed in $1 \%$ agarose.


Figure 7. Cell viability at different concentrations of S8 or Magnevist in (A) MDA-MB-231 cells (B) PC-3 cells.
Cytotoxicity of S8. Through testing the activity of dehydrogenase in the mitochondria, one can indirectly investigate the viability and proliferation of cells. It was found that S8 inhibited the proliferation of tumor cells, and this ability was enhanced with the increasing concentrations. At a concentration of $1.0 \mathrm{mM}$, the relative MDA-MB-231 cell viability was $80 \%$ (Fig. 7A) and that of PC-3 cells was $64.5 \%$ (Fig. 7B). The relative cell viability in response to Magnevist was $>90 \%$ at all concentrations $(0-1.0 \mathrm{mM})$.

\section{Discussion}

The product synthesized in the present study contains two target-specific sequences, RGD and NGR. The two peptide moieties were connected by four serine (Ser) and one glycine (Gly). Ser is a hydrophilic amino acid, which can enhance peptide flexibility and water solubility. The four Ser and one Gly separate RGD from NGR to minimize potential steric interactions which may hamper binding.

Cyclic peptides are considerably more stable than their linear counterparts. Dathe et al (25) reported that cyclic peptides display improved binding affinity to their cellular targets owing to minimal entropy costs for binding. Colomb et al (26) demonstrated that the use of disulfide-bridged cyclic NGR peptide led to a 10 -fold increase in the efficacy of targeting to tumor sites compared to its linear analog. Therefore, in this study, we linked the two Cys by disulfide bridge in order to improve the stability and the binding affinity. The synthesis of the ligand was completed on the solid resin substrate. Solid phase synthesis offers many advantages, such as a high coupling efficiency and convenient purification procedures. The various impurities and the excess reaction substances are easily removed from the 
reaction system by washing with the appropriate solvent. The Gd complex S8 was prepared by adding 0.99 equivalents of $\mathrm{Gd}$ chloride to a solution of S7 in water. A slight excess of S7 was used to ensure the absence of free $\mathrm{Gd}$, which is highly toxic.

From Fig. 5, one can see that the quantity of S8 absorbed by the two cell lines was markedly higher compared with the one absorbed by Magnevist. The difference may be due to the overexpression of $\alpha_{v} \beta_{3}$ in the MDA-MB-231 cells and the overexpression of $\mathrm{CD}_{13}$ in the PC-3 cells, which leads to the binding of RGD and NGR peptides of S8 to $\alpha_{\mathrm{v}} \beta_{3}$ and $\mathrm{CD}_{13}$, respectively. This result indicates that $\mathrm{S} 8$ can specifically target tumor cells overexpressing $\alpha_{\mathrm{v}} \beta_{3}$ and $\mathrm{CD}_{13}$. In addition, it has been demonstrated that the absorption of Magnevist by cells is non-specific. These results are in agreement with our original hypothesis that the combination of the RGD and NGR peptides can create a more efficient targeting contrast agent and can improve tumor detection rates.

Cell imaging experiments have demonstrated that in order to achieve effective cell visualization, relatively high concentrations of the contrast agent must be used. The two cell lines used in this study showed the same uptake rule. However, the effective concentration of S8 was $0.2 \mathrm{mM}$ in MDA-MB-231 and $0.6 \mathrm{mM}$ in PC-3 cells. The imaging of the two cell lines showed that $\alpha_{v} \beta_{3}$ is expressed at higher levels in MDA-MB231 than $\mathrm{CD}_{13}$ is in PC-3 cells, which is consistent with the absorption experiment results. Overall, the dual-targeting contrast agent can bind to tumor cells overexpressing $\alpha_{v} \beta_{3}$ and to tumor cells overexpressing $\mathrm{CD}_{13}$.

The cytotoxicity of Magnevist is lower compared to S8. A possible explanation for this is that Magnevist can rapidly enter and be released from cells due to its low molecular weight. Another explanation may be that the Magnevist quantity absorbed by the cells is limited due to the non-specific nature of Magnevist cell uptake, and therefore, this compound cannot exert cytotoxic effects. Nevertheless, as shown by our results, S8 inhibits the proliferation of tumor cells at high concentrations, which indicates that S8 can bind to tumor cells.

In conclusion, we designed a dual-targeting contrast agent containing RGD and NGR, which has a high $r_{1}$ value (8.297 $\left.\mathrm{mM}^{-1} \mathrm{sec}^{-1}\right)$ and can target tumor cells overexpressing $\alpha_{v} \beta_{3}$ and $\mathrm{CD}_{13}$. Thereby, a single contrast agent can improve tumor detection rates.

\section{Acknowledgements}

This study was financially supported by a Strategic Priority Research Program of the Chinese Academy of Sciences (XDA01030203) and a Basic Research Project from the Ministry of Science and Technology of China (2011CB965004). The MRI facility used in this study is funded by the Chinese Academy of Sciences. The authors would like to thank the Center of Analysis and Test at the Huazhong University of Science and Technology (Wuhan, China) for assistance with ESI-MS and RP-HPLC analyses.

\section{References}

1. Riccabona G and Decristoforo C: Peptide targeted imaging of cancer. Cancer Biother Radiopharm 18: 675-687, 2003.

2. Rudin M and Weissleder R: Molecular imaging in drug discovery and development. Nat Rev Drug Discov 2: 123-131, 2003.
3. Li ZJ and Cho $\mathrm{CH}$ : Peptides as targeting probes against tumor vasculature for diagnosis and drug delivery. J Transl Med 10 (Suppl 1): S1, 2012.

4. Caravan P: Protein-targeted gadolinium-based magnetic resonance imaging (MRI) contrast agents: design and mechanism of action. Acc Chem Res 42: 851-862, 2009.

5. Mitra A, Nan A, Papadimitriou JC, et al: Polymer-peptide conjugates for angiogenesis targeted tumor radiotherapy. Nucl Med Biol 33: 43-52, 2006.

6. Pawar PV, Gohil SV, Jain JP, et al: Functionalized polymersomes for biomedical applications. Polym Chem 4: 3160-3176, 2013.

7. Seward GK, Wei Q and Dmochowski IJ: Peptide-mediated cellular uptake of cryptophane. Bioconjug Chem 19: 2129-2135, 2008.

8. Ye F, Wu X, Jeong EK, Jia Z, et al: A peptide targeted contrast agent specific to fibrin-fibronectin complexes for cancer molecular imaging with MRI. Bioconjug Chem 19: 2300-2303, 2008.

9. Chen XM, Wang X, Huang Y, et al: A comparison study of the targeting properties of NGR liposomes and RGD-liposomes towards human umbilical vein endothelial cells. J Chinese Pharm Sci 18: 162-169, 2009.

10. Beer AJ and Schwaiger M: Imaging of integrin alphavbeta3 expression. Cancer Metastasis Rev 27: 631-644, 2008.

11. Liu S: Radiolabeled cyclic RGD peptides as integrin alpha(v) beta(3)-targeted radiotracers: maximizing binding affinity via bivalency. Bioconjug Chem 20: 2200-2213, 2009.

12. Dijkgraaf I, Kruijtzer JA, Liu S, et al: Improved targeting of the alpha(v)beta(3) integrin by multimerisation of RGD peptides. Eur J Nucl Med Mol Imaging 34: 267-273, 2007.

13. Haukkala J, Laitinen I, Luoto P, et al: 68Ga-DOTA-RGD peptide: biodistribution and binding into atherosclerotic plaques in mice. Eur J Nucl Med Mol Imaging 36: 2058-2067, 2009.

14. Xie J, Chen K, Lee HY, et al: Ultrasmall c(RGDyK)-coated $\mathrm{Fe}_{3} \mathrm{O}_{4}$ nanoparticles and their specific targeting to integrin alpha(v)beta3-rich tumor cells. J Am Chem Soc 130: 7542-7543, 2008.

15. Wang RE, Niu Y, Wu H, et al: Development of NGR peptidebased agents for tumor imaging. Am J Nucl Med Mol Imaging 1: 36-46, 2011.

16. Albrecht S, Al-Lakkis-Wehbe M, Orsini A, et al: Aminobenzosuberone: a novel warhead for selective inhibition of human aminopeptidase-N/CD 13 . Bioorg Med Chem 19: 1434-1449, 2011.

17. Soudy R, Ahmed S and Kaur K: NGR Peptide ligands for targeting $\mathrm{CD}_{13} / \mathrm{APN}$ identified through peptide array screening resemble fibronectin sequences. ACS Comb Sci: Oct 11, 2012 (Epub ahead of print).

18. Negussie AH, Miller JL, Reddy G, et al: Synthesis and in vitro evaluation of cyclic NGR peptide targeted thermally sensitive liposome. J Control Celease 143: 265-273, 2010.

19. Sloan EK, Pouliot N, Stanley KL, et al: Tumor-specific expression of alphavbeta 3 integrin promotes spontaneous metastasis of breast cancer to bone. Breast Cancer Res 8: R20, 2006.

20. Goswami LN, Ma L, Cai Q, et al: cRGD peptide-conjugated icosahedral closo- $\mathrm{B}_{12}(2-)$ core carrying multiple $\mathrm{Gd}^{3+}$-DOTA chelates for $\alpha(\mathrm{v}) \beta_{3}$ integrin-targeted tumor imaging (MRI). Inorg Chem 52: 1701-1709, 2013.

21. Ndinguri MW, Solipuram R, Gambrell RP, et al: Peptide targeting of platinum anti-cancer drugs. Bioconjug Chem 20: 1869-1878, 2009.

22. Mishra AK and Chatal JF: Synthesis of macrocyclic bifunctional chelating agents: 1,4,7-tris(carboxymethyl)-10-(2-amino ethyl)-1,4,7,10-tetraazacyclododecane and 1,4,8-tris (carboxymethyl)-11-(2-aminoethyl)-1,4,8,11-tetraazacyclotetradecane. New J Chem 25: 336-339, 2001.

23. Kates SA, Sole NA, Johnson CR, et al: A novel, convenient, 3-dimensional orthogonal strategy for solid-phase synthesis of cyclic-peptides. Tetrahedron Lett 34: 1549-1552, 1993.

24. Sarin VK, Kent SBH, Tam JP and Merrifield RB: Quantitative monitoring of solid-phase peptide synthesis by the ninhydrin reaction. Anal Biochem 117: 147-157, 1981.

25. Dathe M, Nikolenko H, Klose J and Bienert M: Cyclization increases the antimicrobial activity and selectivity of arginineand tryptophan-containing hexapeptides. Biochemistry 43: 9140-9150, 2004

26. Colombo G, Curnis F, De Mori GM, et al: Structure-activity relationships of linear and cyclic peptides containing the NGR tumor-homing motif. J Biol Chem 277: 47891-47897, 2002. 